\title{
The Dogma of Book Selection in University Libraries
}

By LAWRENCE S. THOMPSON

$\mathrm{T}$ HE PRACTICE of book selection is a basic and abiding aspect of the administration of all types of libraries. Readers and librarians come and go, but books and bibliographies of books remain in one form or another.

Book selection is universal. Even the great national libraries which enjoy effective systems of copyright deposit have their "selection officers." Scaling on down to the smallest libraries, selection becomes increasingly necessary for financial and spatial reasons.

In some instances book selection is easy and completely effective for the purpose at hand, and the librarian's work is almost nil. For example, in the small popular libraries of totalitarian countries acquisitions conform strictly to standard lists from the Ministry of Education. Again, in countries with an old national culture and comparatively small total book production (e.g., Iceland, Denmark, Finland), book selection is relatively uncomplicated for a popular library with only a few hundred dollars a year to acquire the basic belletristic and social science literature in the national language. Neither is it difficult to build the collection of a special library serving a prosperous industry with a relatively small and sharply defined body of technical literature, although housing and discard may be sensitive issues.

In the Handbuch der Bibliothekswissenschaft Fritz Redenbacher devotes some thirty pages to fundamentals of book selection for the research library. While he imparts much practical information, we may only conclude that a reasonably well
Dr. Thompson is Director, University of Kentucky Libraries.

paid librarian might spend several times the price of a book in the time taken to select it. Even then he may or may not have pleased a gratifying portion of readers. We can only tell readers who do not care for selections by librarians and/or professors that they can still depends on microforms, agencies such as the Midwest Inter-Library Center, or general interlibrary loan. A fast-talking librarian can frequently persuade his readers that these are adequate substitutes.

The realistic facts of the problem of book selection in university libraries are: (1) no one person is competent to select individual titles on a broad general basis; (2) the volume of publication is so great that there must be some form of selection; (3) no library has the funds to acquire, the personnel to process, and the space to shelve everything that appears; and (4) who can predict what may be significant for future research in the deluge of preserved information?

There have always been selectors, and on them we may blame much of our lack of information about history or ideas or technical skills of the past. No Mycenaean Greek ever thought that it was more worthwhile to transcribe contemporary ballads in permanent form than to record lists of merchant ships. On the other hand, a small sect around the Dead Sea had more insight about the preserva- 
tion of certain scriptural and exegetical literature than did any of the more prominent contemporaries. There is also the classic story of the Bodleian's first copy of a First Folio.

To be sure, there are certain basic principles of selection in which nearly anybody with some little academic background may acquire competence. For a research library with limited funds anyone knows not to select a superseded edition, a juvenile, a vanity press of selfpublished title, or a work in a language exotic for the library concerned. Even here, however, selection is fraught with traps for the unwary. An edition may be "superseded" by a censored or bowdlerized version. The broad category of juveniles includes hundreds of literary classics. Many a library must order vanity press books for special collections. And thousands of works in exotic languages have significant and comprehensible illustrations or tables or (in the case of scholarly studies) resumés in common western European languages.

These are but a few examples of the multiplicity of problems involved in book selection in university libraries. If any individual, group of individuals, or system can cope adequately and economically with these issues of book selection, the most difficult problem of a century and a half of modern university librarianship would be solved.

Yet what are we to accept and what are we to reject from the hundreds of thousands of books and pamphlets published annually all over the world in various forms of duplication? To be the last Canute, defying the volume, to say nothing of the doubtful quality, of all the world's duplicated records is ridiculous. There must be some method of selection, but it need not necessarily be selection of individual titles. We must seek a basic policy by which to separate, in general, the more urgently needed from the less urgently needed. We must deal in generalities; for if we deal in specifics, the time consumed might well be equivalent to the cost of comprehensive coverage of fields pertinent for the particular library.

We face realities. If we had funds to buy or acquire in some other manner all the duplicated records of man, we would probably not have the personnel to process them. If we had both funds and processing personnel, we would probably not have space to shelve the material. And if we had funds, personnel, and space, the sources of our financial support would be likely to argue that we were eating too high off the hog. These sources-private or governmental-have a right to know our policies of selection, a right to demand that we formulate such policies if they do not already exist, and a right to examine them critically.

But if we have a policy consistent with available funds, if we work out a modus vivendi with the hydra of book production, if we show some intelligence about acceptance or rejection of individual titles, who can be sure that we are providing adequately for the future, that we are filling the specific needs of scholars a generation hence? This question is unanswerable, but it cannot be dismissed. Few university librarians have not seen collections which were the hallmarks of late nineteenth century genteel education but which today can be picked over only for imprints and occasional exceptional nugae. Such collections often represent strong efforts to bring together all the best in the eyes of librarians and professors of the day, but they were, for the most part, failures. Our modern university libraries may be larger in volume, but there is no assurance that their qualitative value will be any greater in the twenty-first century than that of the average nineteenth century collection is for us.

Book selection, as we have known it in university libraries, has resulted in highly miscellaneous collections in all but those largest university libraries 
which approach the status of universal collections. Take, for example, the holdings of any European university library which existed in the eighteenth century and which has suffered no violence. In no instance can we find a comprehensive collection of what we now consider the best books of the age, and in only a few are the national literatures of the period well represented. American university libraries which existed in the nineteenth century are paying fabulous prices for books published in the very regions in which these libraries were flourishing. These books were not necessary for the curriculum, and no selection policies were formulated to cover them.

There have been noteworthy exceptions to the policy of selectivity in collecting contemporary books and pamphlets in specific fields of emphasis, and there is some evidence that this tendency is growing today. George Thomason did an unforgettable service for historical scholarship when he brought together a comprehensive collection of Civil War imprints. The Boston Athenaeum had the vision to do much the same thing for the American Civil War, or, at least, for the material printed in the old rebel states. Herbert Hoover was wise enough not to bother with details of selection in bringing together source material on World War I and related matters.

In general the social sciences are likely to be the greatest headache for the selector of individual titles. The juvenilia of a Napoleon, a Lincoln, or a Hitler are materials that a contemporary selection officer is likely to reject summarily. To be sure, he who tries to show "foresight" will find himself up many a dry creek. No one can guess the turn of political fortunes, but this very circumstance is a strong reason for comprehensive collecting.

Selection is almost as difficult in the field of belletristic literature. One might immediately reply that anyone with the "gentleman's education" for which we aspire for all librarians should be able to draw the line at some point between doggerel and poetry, melodrama and drama. But is the Sweet Singer of Michigan a literary phenomenon we may ignore? Should our colonial colleagues have rejected Michael Wigglesworth and Anne Bradstreet? And I will not mention here the price that one library paid for an exlibrary copy of the first edition of East Lynne adorned with a few scribblings of Ellen Wood. The grand old melodrama wasn't proper company for the middle to highbrow writers on our academic library bookshelves a century ago.

In the biological and physical sciences and in many professional fields selection is not so troublesome. All scientists know the respectable journals. Yet even here who is to recognize an obscure dissertation from Dorpat or a Programmschrift from a country gymnasium in Styria that may contain a basic new statement of a scientific principle. Still, the bulk of printed scientific literature can be identified from a qualitative standpoint. The sub-literature (processed and in microform) is another problem. Since most of it is not evaluated, it must be collected comprehensively if we are not to miss that hundredth title likely to be of supreme importance.

The university librarian has two alternatives when he faces the problem of building collections in the social sciences and the humanities: (1) To allocate all funds to departments and allow the faculty to choose what is needed for the moment, forgetting possible future needs, and depending heavily on interlibrary loan, microfacsimiles, and agencies such as MILC; or (2) to retain in the general fund a substantial portion of his appropriation and allocate large segments for exhaustive coverage of fields of special emphasis, with no regard to selection of individual titles. With the latter alternative he has the possibility of placing selection on a major policy-making level, by separating those fields of major im- 
portance to the institution from fields represented by service departments. Wherever we identify strength, we should aim at comprehensiveness, but always with due consideration to regional and national cooperative acquisition programs. The cheap and less significant literature, after all, costs but a fraction of the truly important pieces; and, within the library, there may be a secondary selection process by which the minor pieces are cataloged and shelved at less expense than the more important titles.

Vertical comprehensive collecting (by subject) is likely to be the only practical application of this principle. Horizontal comprehensiveness, e.g., standing orders with individual publishers or with categories of publishers such as university presses, can bring in a messy batch of miscellaneous titles, some useful, some junk.

Let us assume that a library, rather a university, has decided to give special emphasis to some field. Take, for example, modern Spanish belletristic literature, a not unimportant subject. All non-serial titles in this field can be delivered by a dealer (name available on application) for around $\$ 400-\$ 500$ annually. Again, let us assume that a library wants to cover all problems under current consideration by legislative bodies in the fifty states. Falls City Microcards offers everything in this field, fully cataloged, for about $\$ 500-\$ 600$ a year (depending on the volume of publication).

In certain other fields it is possible to use the international bibliographies, separating the serials and separates. For over a decade I have followed carefully the annual Hirsch-Heaney checklists of bibliographical scholarship in Studies in Bibliography and attempted to acquire virtually everything listed here. It would not be difficult to defend an argument that any respectable university library emphasizing humanistic scholarship should strive to be as complete as possible in this material. With the exception of the occasional very expensive item such as Marinis' great work on the Neapolitan royal library, the non-serial items in this bibliography cost an average of about $\$ 750$ a year, a cheap price for bibliographical soundness in a library.

But what decision might we make in the case of bibliographies such as the Handbook of Latin American Studies or Library Literature? There is patently a much larger proportion of less important material in these bibliographies than in the Hirsch-Heaney checklists. If one examines the acquisition lists of certain large or special libraries in these fields, it is apparent that they are trying to get everything, with no regard to the quality of individual titles. It seems to be generally recognized that if a library is to be a research library in the best sense, it must be comprehensive in its fields of emphasis, including good, bad, and indifferent. The librarian, except perhaps the special librarian, is no more competent to exercise critical judgment in dealing with individual titles out of great masses of literature than is any other mortal. Final critical evaluation is the job of individual scholars.

Still, mass acquisition is not possible without a few bird-dogs in the bibliographical kennel to sniff out the exceptional. For twelve years I have made strong efforts to build the University of Kentucky Library's holdings of European books that are privately printed, privately distributed, or otherwise limited in edition. The purpose is to strengthen the graphic arts collections, since most of these books are significant examples of printing and illustration. Titles must be excavated from review sections of obscure journals, bulletins of bibliophilic societies, and personal correspondence and conversation. The books are generally free, but the cost is high in terms of man-hours spent. However, the result is more than rewarding. In 1957 from this source came sixteen titles not held by Library A with the Farmington 
Plan responsibility for them; four titles not held by Library B; and three not held by Library C, both with this responsibility in other areas.

What about those fields in which a research library does not wish, for one reason or another, to acquire en masse? What about those libraries which should acquire en masse but lack the funds? The answer to the first question is simple: Give the teaching staff and the readers what they want for current use. If the long-term results are less than satisfactory for building a research collection, these libraries won't be much worse off than all but a half dozen or so American university libraries of the sixties. The answer to the second question requires toughness, perhaps unrealistic toughness in terms of what a librarian can say to a president: If a library is to be a research library in the true sense in those fields it selects for emphasis, it must have funds for purchasing, processing, and housing. For the hundred or so American universities which grant a respectable doctorate, this means that serious consideration should be given to comprehensive collecting in one or more fields. If the university cannot provide the necessary funds for the library, it is doubtful whether it can provide the necessary funds for teaching and research; and it is further doubtful whether it should try to offer advanced work at all.

The results of comprehensive collecting are not immediately apparent. A generation or so is necessary before the collections begin to take shape. But how remarkable these results can be! The University of Helsingfors Library enjoyed the privilege of imperial copyright deposit for a little over a century prior to 1917, and it will forever be a precious collection of nineteenth century Russian literature. The Deutsche Bücherei is barely a half a century old, but it is rivalled only by the far older collections of Berlin and Munich as a depository of German cultural tradition. The Biblio- thèque Nordique of the Ste--Geneviève enjoys the good will of nearly all Scandinavian publishers as a depository, and there is no more useful collection of Scandinavica south of Copenhagen.

Beyond the small college library, the problem of selecting individual titles from today's mass of publication is an unrewarding, well-nigh hopeless task for academic librarians. In universities the librarian should attempt to get away from the concept of selection of individual titles in most cases. In fields where there must be selection of individual titles, the teaching staff can handle the job and satisfy itself as best it may. If the teaching staff fails, it can stew in its own bibliological juice; and it is a bitter juice of failure, whether concocted by professors or librarians.

The librarian will be best advised to confine his selecting to policy-making. In conference with colleagues and the teaching staff, he should decide where and when to attempt mass collecting. Such a policy does not prohibit him from soliciting gifts, cultivating angels, developing exchanges, selecting items to fill obvious lacunae in fields he knows well, and otherwise enriching collections. It does prohibit him from attempting, by himself or with fellow librarians, to select piecemeal the five or ten per cent of the world's annual book production that the average American university library can afford.

The dogma of book selection by individual titles has yielded no significant results in university libraries. In fact, our growth seems to be the more haphazard on account of it. We cannot abolish selection by individual titles, for there will always be situations in which the traditional principles of selection must be followed. However, the major acquisition policy should be concerned with whole fields, and the key decisions should revolve around the intensity with which acquisition in these various fields should be pursued. 